\title{
Production Performance of Brinjal (Solanum melongena L.) Genotypes in Laterite Belt of Eastern India
}

\author{
H. R. Parida ${ }^{1}$, J. Mandal ${ }^{1 *}$, N. R. Chakraborty ${ }^{2}$ and S. Mohanta ${ }^{3}$ \\ ${ }^{1}$ Department of Horticulture and Post-Harvest Technology, ${ }^{2}$ Department of Genetics \\ and Plant Breeding, Institute of Agriculture, Visva-Bharati, \\ Sriniketan - 731236 (West Bengal), India \\ ${ }^{3}$ Department of Horticulture, M. S. Swaminathan School of Agriculture, Centurian University \\ of Technology and Management, Paralakhemundi (Odisha) - 761211, India \\ *Corresponding author
}

\section{A B S T R A C T}

Keywords

Solanum melongena,

Solanaceae,

flowering, yield,

West Bengal

Article Info

Accepted:

11 June 2020

Available Online:

10 July 2020
The production potential of thirty five brinjal genotypes was studied under Red and Laterite Zone of West Bengal with the aim to identify suitable genotypes for this region. Considerable variation was observed among the genotypes for various growth, flowering, harvesting and yield attributes. Utkal Anushree and Teispur Long were identified as good producer. Pusa Purple Long, Pusa Ankur, Pusa Upkar, Pusa Anupam and Local-2 genotypes were found as early types, which were suggested to utilize in breeding programme.

\section{Introduction}

Brinjal (Solanum melongena L.) is a popular vegetable crop of tropical and sub-tropical region. India is considered as the primary center of origin (Vavilov, 1931) while China regarded as the secondary center of origin. It is consumed in both fresh and preserved forms. It is mainly cooked as bharta, fried and curry and also used as a raw material for pickle making.
The fruits have some medicinal properties like white brinjal is suggested to diabetic patients (Chauhan, 1981). In India the production of brinjal is about 12399.9 thousand MT from an area of 668.7 thousand ha with productivity of $18.5 \mathrm{MT} / \mathrm{ha}$ in 201617.

Among the Indian states, West Bengal ranks first in area (162.93 thousand ha) and production (3019 thousand MT) while $12^{\text {th }}$ in 
productivity (18.53 MT/ha) in brinjal. However, Uttar Pradesh occupied the first position in productivity (34.34 t/ha) (Department of Agriculture, Cooperation \& Farmers Welfare, 2017). For genetic improvement of any crop collection and evaluation of genotypes is a pre-requisite practice. The success of any breeding program depends on the variation present among the genotypes in that population which provides better scope to the breeder to select the desired genotypes. Various local cultivars / landraces are grown in West Bengal which leads to much low productivity and were often affected by various diseases and pests. Identification of new genotypes with good yield potential, quality and resistance / tolerance against various pest and diseases are needed to uplift the overall productivity of brinjal in Red and Laterite Zone of West Bengal. The farmers of this region should be encouraged to grow the identified superior genotypes for production enhancement. The selected genotypes can also be utilized in hybridization programme for creation of desirable recombinants. With these ideas the present experiment was conducted to study the performance of various brinjal genotypes and identification of superior genotype(s) for Red and Laterite Zone of West Bengal.

\section{Materials and Methods}

The present experiment consists of 35 genotypes of brinjal collected from different areas of West Bengal and India. The experiment was evaluated in Randomized Block Design with three replications at Horticultural Farm of Institute of Agriculture, Sriniketan during Kharif season of 2018-19. The experimental site comes under the Red and Lateritic Zone of West Bengal. The seeds of brinjal genotypes were sown in raised nursery beds. Then month old seedlings were transplanted at a spacing of $75 \mathrm{~cm}$ in both row to row and plant to plant in experimental plots. Five randomly selected plants were tagged from each treatment in each replication for recording different observation like plant height and number of branches per plant at 60 days after planting, days to fifty percent flowering, days to first harvest, harvesting duration, fruit length and width, average fruit weight and fruit number per plant. The yield data was taken many times starting from $3^{\text {rd }}$ week of October (55 DAT) to $1^{\text {st }}$ week of February (165 DAT), which later added to get yield per plot. The yield per hectare was calculated from yield per plot. Initial fresh fruit weight and oven dried fruit weight of each genotype were taken in the departmental laboratory and from that percent fruit dry matter content was worked out. The total variation among the genotypes for different characters was tested for significance by ' $F$ ' test using analysis of variance technique. Critical difference was calculated for each character to test the significance of difference among the treatment means of different genotypes (Fisher and Yates, 1963).

\section{Results and Discussion}

Signification variation was observed among the brinjal genotypes for all the studied characters. The mean performance of genotypes for different characters has been presented in Table 1 to 3 and discussed.

\section{Vegetative traits}

Plant height was varied between 66.7 and 113 $\mathrm{cm}$ with an average value of $95.1 \mathrm{~cm}$. Maximum plant height was observed in genotype Local-5, which were noted statistically at par with Muktakeshi-4, Muktakeshi-5, Special Bhangar Brinjal, Local-1, Muktakeshi-1, Brinjal Blue Star, Muktakeshi-2, Long Purple, Teispur Long, Pusa Purple Round, Long White, Local-3, Green 20/20, Pant Samrat, Local-7, Mini, 
Pusa Purple Cluster and Brinjal Amrapali. The number of branches per plant was ranged from 7.3 to 12.8 with an overall mean of 10.0. Highest number of branches per plant was found in Pusa Anupam, which was noted statistically similar to Muktakeshi-4, Brinjal Blue Star, Pant Samrat, Teispur Long, Utkal Anushree, Green 20/20, Muktakeshi-1, Special Bhangar Brinjal, Local-3, Pusa Purple Round, Local-1, Local-2, Muktakeshi-5, Local-7, Rajgao and Pusa Purple Long. The variation in vegetative characters was also reported by Tripathi et al., (2009), Lokesh et al., (2013), Sanas et al., (2014) and Akshay et al., (2018). Plants with optimum height and medium branches are desirable for vegetative growth in brinjal.

\section{Flowering and harvesting traits}

Days to fifty percent flowering, days to first harvest and harvesting duration (days) are the three important parameters which are related to earliness and yield. Number of days required for fifty percent flowering was varied from 37.3 to 67.7 . On the other hand, number of days required for first fruit harvest was varied between 57.7 and 84.7. The range of data indicated the presence of good variation among the genotypes. Thus further selection can be practiced for this trait in the studied brinjal population. The mean value for fifty percent flowering and average number of days required for first fruit harvesting was noted 53.8 and 69.5 days respectively.

The minimum number of days required for fifty percent flowering was recorded in Pusa Purple Long, which was recorded statistically at par with Pusa Ankur, Pusa Upkar, Local-2, Pusa Anupam and Muktakeshi-4. Significant variation in days to fifty percent flowering in brinjal was also observed by Chattopadhyay et al., (2011) and Vidhya and Kumar (2015). Minimum number of days required for first fruit harvest was recorded in Naveen SGS-2,
Pusa Purple Long, Local-2 and BR-112 closely followed by Pusa Anupam, Pusa Upkar, Brinjal Amrapali, Local-1, Pusa Ankur, Brinjal Blue Star, Local-3, Pant Samrat, Muktakeshi-2, Utkal Anushree, Kalo Sayla, Pusa Purple Cluster, Teispur Long, Muktakeshi-1, Local-4 and Local-6. Sanas et al., (2014) and Akshay et al., (2018) reported variation for days to first harvest in brinjal. The harvesting duration was varied from 5.7 to 106 with an average value of 69.9 days. Maximum period of fruit harvesting was found in genotype Pusa Anupam, which was recorded statistically at par with Brinjal Amrapali, Local-1, Brinjal Blue Star, Local-3, Utkal Anushree, Kalo Sayla, Pusa Purple Cluster, Teispur Long, Muktakeshi-1, Local6, Muktakeshi-4, Bhangar, Special Bhangar Brinjal, Local-5, Green 20/20, Long White, Local-7, Makra, Muktakeshi-5, Dark Purple, and Mini. On the other hand, shorter harvesting duration was recorded in Pusa Ankur, closely followed by Naveen SGS-2, BR-112, Pusa Bhairav, Pusa Purple Long, Pant Samrat, Long Purple and Pusa Upkar. Sanas et al., (2014) recorded variation for harvesting duration in brinjal.

\section{Yield and yield traits}

Fruit length and width was varied between 7.8 and $20.7 \mathrm{~cm}$ and 32.1 and $79.1 \mathrm{~mm}$ respectively. The mean fruit length and width was found $13.0 \mathrm{~cm}$ and $57.8 \mathrm{~mm}$ respectively. Maximum fruit length was observed in genotype Pusa Purple Long, which was found statistically similar to Long White and Long Purple.

Similarly, maximum fruit width was recorded in genotype Local-6, which was noted statistically at par with Pusa Purple Round, Makra, Muktakeshi-1, BR-112, Muktakeshi-4 and Kalo Sayla. The Average fruit weight was ranged from 19.9 to $255.3 \mathrm{~g}$ with an overall mean of $128.7 \mathrm{~g}$. 
Table.1 Mean performance of vegetative and fruit maturity characters in Brinjal

\begin{tabular}{|c|c|c|c|c|c|}
\hline Genotypes & $\begin{array}{c}\text { Plant } \\
\text { height }(\mathrm{cm})\end{array}$ & $\begin{array}{l}\text { Number of } \\
\text { branches } \\
\text { per plant }\end{array}$ & $\begin{array}{c}\text { Days to Fifty } \\
\text { percent } \\
\text { flowering }\end{array}$ & $\begin{array}{c}\text { Days to } \\
\text { first } \\
\text { harvest }\end{array}$ & $\begin{array}{c}\text { Harvesting } \\
\text { duration } \\
\text { (days) }\end{array}$ \\
\hline Special BhangarBrinjal & 106.8 & 11.3 & 50.0 & 75.7 & 89.3 \\
\hline BrinjalAmrapali & 95.6 & 8.2 & 48.7 & 61.7 & 103.3 \\
\hline Naveen SGS-2 & 87.3 & 8.3 & 62.3 & 57.7 & 9.3 \\
\hline Muktakeshi-2 & 101.8 & 8.2 & 50.3 & 66.0 & 72.0 \\
\hline Pant Samrat & 97.7 & 12.0 & 57.3 & 64.7 & 20.0 \\
\hline Brinjal Blue Star & 104.2 & 12.0 & 47.0 & 64.3 & 100.7 \\
\hline Muktakeshi-1 & 105.8 & 11.3 & 53.7 & 70.0 & 95.0 \\
\hline Muktakeshi-4 & 111.5 & 12.7 & 45.3 & 73.0 & 92.0 \\
\hline Pusa Purple Round & 99.5 & 11.2 & 59.0 & 73.0 & 56.0 \\
\hline PusaAnkur & 82.8 & 7.7 & 39.7 & 63.3 & 5.7 \\
\hline PusaAnupam & 92.3 & 12.8 & 43.3 & 59.0 & 106.0 \\
\hline PusaBhairav & 78.4 & 8.7 & 52.7 & 74.3 & 12.3 \\
\hline PusaUpkar & 83.7 & 8.7 & 42.0 & 60.3 & 36.3 \\
\hline Pusa Purple Long & 81.2 & 10.3 & 37.3 & 57.7 & 15.3 \\
\hline Pusa Purple Cluster & 97.2 & 9.7 & 51.3 & 67.3 & 97.7 \\
\hline UtkalAnushree & 92.3 & 11.5 & 46.7 & 66.0 & 99.0 \\
\hline Local-7 & 97.6 & 10.5 & 56.3 & 78.7 & 86.3 \\
\hline Local-2 & 94.1 & 10.7 & 42.7 & 57.7 & 44.7 \\
\hline Local-1 & 106.1 & 10.7 & 57.0 & 61.7 & 103.3 \\
\hline Local-3 & 99.4 & 11.2 & 52.0 & 64.3 & 100.7 \\
\hline Local-5 & 113.0 & 9.7 & 52.3 & 75.7 & 89.3 \\
\hline Local-4 & 91.6 & 8.8 & 61.0 & 70.0 & 41.0 \\
\hline Local-6 & 99.9 & 9.8 & 58.3 & 70.0 & 95.0 \\
\hline Teispur Long & 100.0 & 11.5 & 56.3 & 67.3 & 97.7 \\
\hline Green 20/20 & 98.8 & 11.3 & 57.0 & 76.0 & 89.0 \\
\hline Makra & 90.1 & 8.7 & 62.3 & 80.7 & 84.3 \\
\hline Dark Purple & 82.5 & 7.3 & 60.3 & 80.7 & 81.0 \\
\hline Long Purple & 101.5 & 9.0 & 67.7 & 78.3 & 25.7 \\
\hline Long White & 99.4 & 9.0 & 61.7 & 76.0 & 89.0 \\
\hline Mini & 97.5 & 9.2 & 65.0 & 84.7 & 80.3 \\
\hline Bhangar & 89.8 & 9.7 & 67.0 & 73.0 & 92.0 \\
\hline KaloSayla & 87.3 & 9.0 & 52.0 & 66.0 & 99.0 \\
\hline Rajgao & 89.0 & 10.3 & 55.0 & 78.7 & 45.7 \\
\hline BR-112 & 66.7 & 8.0 & 55.0 & 57.7 & 9.3 \\
\hline Muktakeshi-5 & 107.9 & 10.5 & 59.0 & 81.3 & 83.7 \\
\hline Mean & 95.1 & 10.0 & 53.8 & 69.5 & 69.9 \\
\hline C.D. $(P=0.05)$ & 17.8 & 2.6 & 9.2 & 13.5 & 33.1 \\
\hline
\end{tabular}


Table.2 Mean performance of fruiting characters in brinjal

\begin{tabular}{|c|c|c|c|c|c|}
\hline Genotypes & $\begin{array}{c}\text { Fruit Length } \\
\text { (cm) }\end{array}$ & $\begin{array}{l}\text { Fruit width } \\
\quad(\mathbf{m m})\end{array}$ & $\begin{array}{c}\text { Average fruit } \\
\text { weight (g) }\end{array}$ & $\begin{array}{c}\text { Fruit } \\
\text { number per } \\
\text { plant }\end{array}$ & $\begin{array}{c}\text { Fruit dry } \\
\text { matter } \\
\text { content }(\%)\end{array}$ \\
\hline $\begin{array}{l}\text { Special } \\
\text { BhangarBrinjal }\end{array}$ & 16.5 & 60.8 & 131.6 & 10.9 & 8.1 \\
\hline BrinjalAmrapali & 13.3 & 59.5 & 117.9 & 15.8 & 8.2 \\
\hline Naveen SGS-2 & 9.7 & 38.2 & 98.4 & 0.3 & 7.8 \\
\hline Muktakeshi-2 & 13.6 & 61.8 & 116.0 & 7.6 & 8.6 \\
\hline Pant Samrat & 14.0 & 38.6 & 113.2 & 2.7 & 8.2 \\
\hline Brinjal Blue Star & 11.8 & 65.2 & 137.4 & 15.4 & 9.3 \\
\hline Muktakeshi-1 & 14.8 & 75.9 & 175.2 & 8.4 & 7.6 \\
\hline Muktakeshi-4 & 10.6 & 72.9 & 196.9 & 7.7 & 9.3 \\
\hline Pusa Purple Round & 8.7 & 78.5 & 103.2 & 5.8 & 9.7 \\
\hline PusaAnkur & 9.4 & 63.9 & 93.2 & 3.1 & 8.8 \\
\hline PusaAnupam & 10.9 & 39.1 & 28.4 & 24.8 & 6.7 \\
\hline PusaBhairav & 8.4 & 63.4 & 131.6 & 2.8 & 9.0 \\
\hline PusaUpkar & 7.8 & 62.1 & 82.7 & 14.8 & 9.0 \\
\hline Pusa Purple Long & 20.7 & 37.4 & 82.5 & 11.4 & 9.2 \\
\hline Pusa Purple Cluster & 10.5 & 32.1 & 19.9 & 36.0 & 7.7 \\
\hline UtkalAnushree & 8.1 & 41.1 & 47.0 & 45.0 & 10.0 \\
\hline Local-7 & 18.4 & 36.5 & 102.8 & 13.6 & 8.5 \\
\hline Local-2 & 11.8 & 68.7 & 126.8 & 5.1 & 10.9 \\
\hline Local-1 & 11.8 & 69.1 & 232.3 & 6.4 & 9.2 \\
\hline Local-3 & 15.2 & 52.3 & 152.3 & 8.7 & 8.6 \\
\hline Local-5 & 15.8 & 50.2 & 161.2 & 10.1 & 8.7 \\
\hline Local-4 & 13.3 & 64.6 & 131.3 & 6.7 & 8.4 \\
\hline Local-6 & 8.4 & 79.1 & 255.3 & 5.9 & 7.8 \\
\hline Teispur Long & 17.2 & 51.1 & 80.3 & 26.4 & 9.0 \\
\hline Green 20/20 & 10.0 & 64.4 & 153.3 & 12.2 & 8.4 \\
\hline Makra & 11.1 & 77.3 & 208.6 & 6.7 & 8.4 \\
\hline Dark Purple & 15.8 & 63.2 & 131.9 & 8.2 & 7.7 \\
\hline Long Purple & 19.2 & 41.9 & 132.1 & 4.5 & 10.9 \\
\hline Long White & 20.5 & 35.0 & 87.9 & 17.1 & 8.8 \\
\hline Mini & 17.4 & 54.1 & 142.6 & 9.5 & 10.3 \\
\hline Bhangar & 16.7 & 52.4 & 164.6 & 10.6 & 8.5 \\
\hline KaloSayla & 12.6 & 72.6 & 154.3 & 7.4 & 7.6 \\
\hline Rajgao & 10.1 & 68.6 & 175.5 & 7.5 & 6.7 \\
\hline BR-112 & 8.3 & 73.4 & 104.2 & 0.2 & 10.0 \\
\hline Muktakeshi-5 & 12.4 & 56.6 & 130.9 & 2.5 & 6.9 \\
\hline Mean & 13.0 & 57.8 & 128.7 & 10.9 & 8.6 \\
\hline C.D. $(P=0.05)$ & 1.7 & 7.6 & 13.8 & 1.9 & 1.3 \\
\hline
\end{tabular}


Table.3 Yield of brinjal genotypes in different harvest

\begin{tabular}{|c|c|c|c|c|c|c|c|c|c|c|c|c|c|c|}
\hline \multicolumn{15}{|c|}{ YIELD (quintal / ha) } \\
\hline Genotypes & $\begin{array}{c}\text { 1st } \\
\text { harvest } \\
\text { (55DAT) }\end{array}$ & $\begin{array}{c}\text { 2nd } \\
\text { harvest } \\
\text { (59 DAT) }\end{array}$ & $\begin{array}{c}\text { 3rd } \\
\text { harvest } \\
\text { (67DAT) }\end{array}$ & $\begin{array}{c}\text { 4th } \\
\text { harvest } \\
\text { (76DAT) }\end{array}$ & $\begin{array}{c}\text { 5th } \\
\text { harvest } \\
\text { (84DAT) }\end{array}$ & $\begin{array}{c}\text { 6th } \\
\text { harvest } \\
\text { (90DAT) }\end{array}$ & $\begin{array}{c}\text { 7th } \\
\text { harvest } \\
\text { (94DAT) }\end{array}$ & $\begin{array}{c}\text { 8th } \\
\text { harvest } \\
\text { (99DAT) }\end{array}$ & $\begin{array}{c}\text { 9th } \\
\text { harvest } \\
\text { (109DAT) }\end{array}$ & $\begin{array}{c}\text { 10th } \\
\text { harvest } \\
\text { (124DAT) }\end{array}$ & $\begin{array}{c}\text { 11th } \\
\text { harvest } \\
\text { (138DAT) }\end{array}$ & $\begin{array}{c}\text { 12th } \\
\text { harvest } \\
\text { (155DAT) }\end{array}$ & $\begin{array}{c}\text { 13th } \\
\text { harvest } \\
\text { (165DAT) }\end{array}$ & $\begin{array}{l}\text { Total } \\
\text { yield }\end{array}$ \\
\hline Special BhangarBrinjal & 0.0 & 0.0 & 4.9 & 6.6 & 28.7 & 2.4 & 3.4 & 7.9 & 15.8 & 18.2 & 9.3 & 17.3 & 24.9 & 139.4 \\
\hline BrinjalAmrapali & 0.0 & 4.1 & 6.3 & 27.6 & 36.7 & 9.5 & 6.9 & 31.4 & 29.4 & 43.1 & 21.7 & 16.4 & 21.6 & 254.7 \\
\hline Naveen SGS-2 & 0.8 & 0.0 & 1.2 & 0.0 & 0.0 & 0.0 & 0.0 & 0.0 & 0.0 & 0.0 & 0.0 & 0.0 & 0.0 & 2.0 \\
\hline Muktakeshi-2 & 2.2 & 0.0 & 5.6 & 9.3 & 18.5 & 6.4 & 2.4 & 0.0 & 18.7 & 3.5 & 15.8 & 5.8 & 10.9 & 99.1 \\
\hline Pant Samrat & 0.0 & 1.7 & 0.8 & 4.8 & 3.3 & 0.0 & 2.1 & 0.0 & 0.0 & 0.0 & 0.0 & 0.0 & 0.0 & 12.7 \\
\hline Brinjal Blue Star & 0.0 & 1.6 & 9.5 & 20.8 & 43.5 & 5.1 & 0.0 & 28.3 & 25.3 & 38.2 & 27.3 & 20.5 & 28.4 & 248.5 \\
\hline Muktakeshi-1 & 0.0 & 0.0 & 5.6 & 15.9 & 38.4 & 4.4 & 2.1 & 9.7 & 1.7 & 13.3 & 10.4 & 11.0 & 47.4 & 159.9 \\
\hline Muktakeshi-4 & 0.0 & 0.0 & 5.7 & 6.0 & 23.8 & 4.2 & 1.8 & 19.9 & 6.8 & 14.8 & 20.7 & 10.5 & 31.4 & 145.6 \\
\hline Pusa Purple Round & 0.0 & 0.0 & 0.0 & 12.7 & 11.6 & 0.0 & 2.6 & 8.9 & 1.8 & 3.7 & 5.1 & 1.3 & 3.1 & 50.8 \\
\hline PusaAnkur & 3.0 & 1.8 & 3.1 & 6.2 & 0.0 & 0.0 & 0.0 & 0.0 & 0.0 & 0.0 & 0.0 & 0.0 & 0.0 & 14.1 \\
\hline PusaAnupam & 5.0 & 1.2 & 9.5 & 18.6 & 18.1 & 0.0 & 3.5 & 26.7 & 11.2 & 12.0 & 14.6 & 10.8 & 8.0 & 139.2 \\
\hline PusaBhairav & 1.8 & 1.3 & 6.2 & 2.8 & 5.0 & 0.0 & 0.0 & 0.0 & 3.7 & 0.0 & 0.0 & 0.0 & 0.0 & 20.8 \\
\hline PusaUpkar & 3.2 & 2.5 & 6.7 & 6.5 & 2.8 & 0.0 & 0.0 & 0.0 & 0.0 & 0.0 & 3.8 & 3.4 & 0.0 & 28.9 \\
\hline Pusa Purple Long & 4.2 & 4.5 & 6.9 & 5.5 & 3.7 & 0.0 & 0.0 & 0.0 & 0.0 & 0.0 & 0.0 & 0.0 & 0.0 & 24.8 \\
\hline Pusa Purple Cluster & 0.0 & 1.0 & 4.2 & 22.7 & 31.0 & 0.0 & 5.7 & 31.4 & 22.5 & 19.0 & 16.0 & 8.4 & 8.4 & 170.3 \\
\hline UtkalAnushree & 1.9 & 2.2 & 15.2 & 40.3 & 57.7 & 0.0 & 0.0 & 66.1 & 45.3 & 21.1 & 19.3 & 16.3 & 7.3 & 292.7 \\
\hline Local-7 & 0.0 & 0.0 & 0.0 & 6.6 & 19.4 & 5.9 & 12.3 & 10.1 & 23.1 & 25.0 & 17.8 & 9.5 & 15.7 & 145.4 \\
\hline Local-2 & 4.4 & 2.2 & 4.7 & 16.8 & 8.5 & 0.0 & 2.4 & 0.0 & 0.0 & 2.4 & 0.0 & 0.0 & 0.0 & 41.4 \\
\hline Local-1 & 0.0 & 2.8 & 3.4 & 13.5 & 24.8 & 0.0 & 9.3 & 1.7 & 16.6 & 12.0 & 17.9 & 7.8 & 30.2 & 139.9 \\
\hline Local-3 & 0.0 & 0.9 & 7.2 & 16.0 & 23.0 & 0.0 & 3.1 & 24.1 & 18.7 & 20.9 & 4.8 & 7.3 & 15.2 & 141.2 \\
\hline Local-5 & 0.0 & 0.0 & 3.3 & 8.0 & 23.0 & 6.1 & 0.0 & 21.1 & 26.2 & 24.3 & 11.4 & 6.7 & 25.2 & 155.3 \\
\hline Local-4 & 0.0 & 0.0 & 3.5 & 8.0 & 17.9 & 0.0 & 0.0 & 5.4 & 9.5 & 5.2 & 0.0 & 2.8 & 5.9 & 58.1 \\
\hline Local-6 & 0.0 & 0.0 & 3.9 & 9.4 & 18.0 & 0.0 & 0.0 & 6.9 & 25.4 & 21.6 & 24.1 & 14.6 & 27.6 & 151.6 \\
\hline Teispur Long & 0.0 & 1.2 & 2.9 & 26.5 & 50.2 & 3.4 & 14.9 & 36.5 & 31.3 & 54.2 & 29.6 & 21.0 & 15.2 & 286.8 \\
\hline Green 20/20 & 0.0 & 0.0 & 0.0 & 19.0 & 18.6 & 0.0 & 5.4 & 26.1 & 35.5 & 54.0 & 42.1 & 22.4 & 24.9 & 248.1 \\
\hline Makra & 0.0 & 0.0 & 1.2 & 5.5 & 13.2 & 0.0 & 7.4 & 15.6 & 16.8 & 22.9 & 20.9 & 9.7 & 26.1 & 139.3 \\
\hline Dark Purple & 0.0 & 0.0 & 0.9 & 7.7 & 15.8 & 3.1 & 4.5 & 7.6 & 10.2 & 34.8 & 21.5 & 13.3 & 17.0 & 136.4 \\
\hline Long Purple & 0.0 & 0.0 & 0.0 & 0.0 & 4.7 & 3.1 & 0.0 & 3.0 & 0.0 & 0.0 & 2.7 & 0.0 & 0.0 & 13.5 \\
\hline Long White & 0.0 & 0.0 & 0.0 & 10.0 & 6.9 & 5.9 & 9.5 & 9.2 & 29.4 & 54.1 & 37.1 & 12.1 & 27.7 & 201.9 \\
\hline Mini & 0.0 & 0.0 & 0.0 & 3.3 & 10.4 & 4.1 & 8.1 & 18.4 & 42.5 & 33.7 & 12.0 & 20.6 & 22.4 & 175.5 \\
\hline Bhangar & 0.0 & 0.0 & 2.2 & 4.1 & 19.0 & 3.0 & 9.4 & 31.2 & 15.8 & 24.9 & 21.2 & 14.6 & 25.8 & 171.2 \\
\hline KaloSayla & 1.4 & 0.0 & 0.9 & 9.3 & 14.9 & 7.0 & 3.1 & 9.9 & 10.1 & 27.5 & 9.3 & 12.7 & 27.7 & 133.8 \\
\hline Rajgao & 0.0 & 0.0 & 0.0 & 5.3 & 7.0 & 0.0 & 0.0 & 3.2 & 5.2 & 9.4 & 2.7 & 6.4 & 12.7 & 51.9 \\
\hline BR-112 & 0.0 & 1.4 & 0.8 & 0.0 & 0.0 & 0.0 & 0.0 & 0.0 & 0.0 & 0.0 & 0.0 & 0.0 & 0.0 & 2.2 \\
\hline Muktakeshi-5 & 0.0 & 0.0 & 0.0 & 0.0 & 4.5 & 0.0 & 0.0 & 6.5 & 0.0 & 13.3 & 2.6 & 7.7 & 11.1 & 45.7 \\
\hline GM & 0.8 & 0.9 & 3.6 & 10.7 & 17.8 & 2.1 & 3.4 & 13.3 & 14.2 & 17.9 & 12.6 & 8.9 & 14.9 & 121.2 \\
\hline C.D. $(P=0.05)$ & 0.3 & 0.3 & 1.3 & 3.5 & 5.0 & 0.6 & 1.1 & 4.1 & 4.8 & 5.4 & 3.8 & 2.6 & 4.9 & 13.6 \\
\hline
\end{tabular}


Maximum average fruit weight was observed in genotype Local-6, whereas minimum average fruit weight was observed in Pusa Purple Cluster and Pusa Anupam. Tripathi et al., (2009), Munnipian et al., (2010), Chattopadhyay et al., (2011) and Lokesh et al., (2013) recorded variation in fruit length, width and average fruit weight in brinjal. Nayak and Nagre (2013) found positive and significant correlation between fruit length, width and average fruit weight with yield. A good variation was observed in fruit number per plant in the studied brinjal genotypes. Number of fruits was varied between 0.2 and 45.0. Maximum number of fruits per plant was recorded in genotype Utkal Anushree; whereas minimum number of fruits per plant was recorded in BR-112 and Naveen SGS-2.

Yadav et al., (2017) reported fruit number per plant had positive correlation and direct effect with yield. Ample variation was observed for fruit yield in different brinjal genotypes. The yield was varied from 2.0 to $292.7 \mathrm{q} /$ ha with an average yield of $121.2 \mathrm{q} / \mathrm{ha}$. The maximum fruit yield was observed in Utkal Anushree, which was recorded statistically at par with Teispur Long. Satesh Kumar et al., (2011) and Sanas et al., (2014) also reported variation in fruit number per plant and yield. Fruit dry matter content was varied between 6.7 to $10.9 \%$ with an average of $8.6 \%$.

Maximum fruit dry matter content were recorded in Local-2 and Long Purple, which was noted statistically at par with Mini, Utkal Anushree, BR-112 and Pusa Purple Round. The variation in fruit dry matter content in brinjal was also reported by Shilpa et al., (2018). Final yield of brinjal depends upon the size of the fruit, number of fruits per plant and the fruit dry matter content. All yield related traits had good variation among the genotypes which can be utilized for improvement programme.

The present study has identified a good amount of variability for important economic and agronomic characters. It also demonstrated that there are great possibilities for improving qualitative and quantitative traits by use of appropriate recombination breeding approaches. Recombination breeding is the most effective methods of plant breeding to induce desirable character in locally adapted varieties. Pusa Purple Long, Pusa Ankur, Pusa Upkar, Pusa Anupam and Local-2 genotypes were identified as early types. So these genotypes can be used in breeding programme to induce earliness in progenies. Utkal Anushree and Teispur Long recorded highest yield per hectare. Therefore, these two genotypes can be utilized for yield enhancement programme and simultaneously can be advocated to the local growers for cultivation under Red and Laterite Zone of West Bengal.

\section{References}

Akshay, D.A., S. Praneetha, P.I. Vethamoni and Rajeswari, S. 2018. Mean performance of brinjal (Solanum melongena L.) genotypes under Tamil Nadu condition. J. Agric. and Ecol. 6: 47-53.

Chattopadhyay, A., S. Dutta and Hazra, P. 2011. Characterization of genetic resources and identification of selection indices of brinjal (Solanum melongena L.) grown in eastern India. Vegetable crops research bulletin. 74: 39-49.

Chauhan, D.V.S. 1981. Vegetable production in India (III ${ }^{\text {rd }}$ ed.). Ram Prasad and Sons, Agra, India.

Department of Agriculture, Cooperation \& Farmers Welfare. 2017. Horticulture Statistics at a Glance Ministry of Agriculture and Farmers Welfare, Government of India, pp: 149, 196.

Fisher, R.A., and Yates, F. 1963. Statistical Tables for Biological, Agricultural and Medical Research. Longman Group Ltd. 
Essex, England.

Lokesh, B., P.S. Reddy, R.V.S.K. Reddy and Sivaraj, N. 2013. Variability, heritability and genetic advance studies in Brinjal (Solanum melongena L.). Electron. J. Plant Breed. 4(1): 10971100.

Muniappan, S., K. Saravanan and Ramya, B. 2010. Studies on Genetic Divergence and Variability For Certain Economic Characters in Eggplant (Solanum melongena L.). Electronic Journal of Plant Breeding. 1(4): 462-465.

Nayak, B.R., and Nagre, P.K. 2013. Genetic variability and correlation studies in brinjal (Solanum melongena L.). International Journal of Applied Biology and Pharmaceutical Technology. 4(4): 211-215.

Sanas, M.P., S.M. Shinde, A.P. Sanasand Haldavanekar, P.C. 2014. Performance of Different Types of Brinjal for their Growth and Yield Characters. Int. J. Trop. Agric. 32(3/4): 357-359.

Satesh Kumar, J.P. Sharma and Chopra, S. 2011. Studies on variability, heritability and genetic advance for morphological and yield traits in brinjal (Solanum melongena L.). Mysore Journal of
Agricultural Sciences. 45(1): 63-66.

Shilpa, B.M., R.M. Dheware and Kolekar, R.B. 2018. Variability Studies in Brinjal (Solanum melongena L.). International Journal of Bio-resource and Stress Management. 9(5): 576-579.

Tripathi, M.K., A.K. Singh, B.K. Singh and Rat, V.K. 2009. Genetic variability, heritability and genetic advance among different quantitative characters of brinjal (Solanum melongena L.). Haryana J. Hortic. Sci. 38(3/4): 334335.

Vavilov, N.I. 1931. The role of central Asia in the origin of cultivated plants. Bull. Appl. Bot. Genet. \& Plant Breed. 26(3): 3-44.

Vidhya, C., and Kumar, N. 2015. Genetic variability and performance studies of brinjal (Solanum melongena L.) for fruit yield and quality. Trends in Biosciences, 8(6): 1525-1528.

Yadav, S., V.B. Singh, R. Maurya, and Thapliyal, V. 2018. Correlation and Path Coefficient Analysis in Brinjal (Solanum melongena L.). Int. J. Curr. Microbiol. and Appl. Sci. 7(11): 31823190.

\section{How to cite this article:}

Parida. H. R., J. Mandal, N. R. Chakraborty and Mohanta. S. 2020. Production Performance of Brinjal (Solanum melongena L.) Genotypes in Laterite Belt of Eastern India. Int.J.Curr.Microbiol.App.Sci. 9(07): 912-919. doi: https://doi.org/10.20546/ijcmas.2020.907.106 